\title{
New Insight into Partial Denitrification (PD)-based Anammox Process and Potential Engineering Application: A Review
}

\author{
Fahmi Bahtiar ${ }^{1}$, Xingxing Zhang ${ }^{1}$, Yuguang Wang ${ }^{1}$, Chaochao Wang ${ }^{1}$, Yunkang Xia ${ }^{1}$, Peng Wu ${ }^{1,2,3}$, \\ Lezhong $\mathrm{Xu}^{1,2,3}$, *
}

${ }^{1}$ School of Environmental Science and Engineering, Suzhou University of Science and Technology, Suzhou, China

${ }^{2}$ National and Local Joint Engineering Laboratory of Municipal Sewage Resource Utilization Technology, Suzhou, China

${ }^{3}$ Jiangsu Collaborative Innovation Center of Technology and Material of Water Treatment, Suzhou, China

Email address:

kgre505@163.com (Lezhong Xu)

${ }^{*}$ Corresponding author

\section{To cite this article:}

Fahmi Bahtiar, Xingxing Zhang, Yuguang Wang, Chaochao Wang, Yunkang Xia, Peng Wu, Lezhong Xu. New Insight into Partial Denitrification (PD)-based Anammox Process and Potential Engineering Application: A Review. Journal of Health and Environmental Research. Vol. 6, No. 3, 2020, pp. 79-86. doi: 10.11648/j.jher.20200603.15

Received: July 16, 2020; Accepted: July 29, 2020; Published: August 4, 2020

\begin{abstract}
Recently reported partial denitrification $\left(\mathrm{PD}, \mathrm{NO}_{3}{ }^{-}-\mathrm{N} \rightarrow \mathrm{NO}_{2}^{-}-\mathrm{N}\right.$ ) has attracted extensive attention as a novel promising alternative for anaerobic ammonium oxidation (anammox)-based process. Flexible and stable nitrite $\left(\mathrm{NO}_{2}^{-}-\mathrm{N}\right)$ supply via PD provides substantial electron acceptors for sustainable and economic anammox wastewater treatment with simple control and minimal cost. However, our understanding of researches on PD-based anammox processes applied in biological wastewater treatment is still limited. Given obviously advantages for PD-based anammox (PDA) coupling process held and countless researches have been developed, the major objective of this study was to review the latest advances of which, key influencing factors, principled characteristics and economical analyses. Comprehensive knowledge of PDA engineering application prospects were also helpful to deepen our understanding of its practices, i.e., advanced nitrogen removal from tertiary municipal sewage, post-anammox treatment of nitrogen-rich wastewater and simultaneous nitrogen removal from domestic and nitrate $\left(\mathrm{NO}_{3}{ }^{-} \mathrm{N}\right)$ contained wastewater. Ultimately, future researches trend of PDA was prospected to enlarge its application into full-scale wastewater treatment. In summary, PD-based anammox process held obvious advantages in actual wastewater treatment through efficiently ammonia and nitrate removal, providing a new insight into retrofitting current wastewater treatment plants. Additionally, more attention should be paid to exploring the complicated metabolic network of different types of bacteria in the PD and anammox integration system.
\end{abstract}

Keywords: Partial Denitrification (PD), Anammox, Biological Nitrogen Removal, Coupling Process, Engineering Application

\section{Introduction}

Conventional biological nitrification-denitrification process has been widespreadly developed in current municipal wastewater treatment plants (MWTPs), in which aerobic nitrifying bacteria converted ammonium $\left(\mathrm{NH}_{4}{ }^{+} \mathrm{N}\right)$ into nitrate $\left(\mathrm{NO}_{3}^{-}-\mathrm{N}\right)$ with oxygen $\left(\mathrm{O}_{2}\right)$ as electron acceptor, followed by anoxic denitrifying bacteria would conduct denitrification to reduce $\mathrm{NO}_{3}^{-}-\mathrm{N}$ to nitrogen gas under sufficient organic condition $[1,2]$. However, large amout of aeration investment and chemical addition resulted in energy-intensive process, which was far away from future-oriented novel concept MWTPs in China. Anaerobic ammonium oxidation (anammox) process has attracted extensive attention as an energy-efficient and environmental-friendly strategy to retrofit existing plants, because of its obvious advantages such as $60 \%$ lack in oxygen demand, $100 \%$ decrease in organic carbon requirement and less/no $\mathrm{N}_{2} \mathrm{O}$ (global warming 
potential of 310) emission [3, 4]. In this technology, the ratio of $\mathrm{NH}_{4}{ }^{+}-\mathrm{N}$ to $\mathrm{NO}_{2}{ }^{-} \mathrm{N}$ about $1: 1.30$ is needed for anammox, whereas the latter substrate was rarely discovered in the real wastewater [5]. This means $\mathrm{NO}_{2}^{-}-\mathrm{N}$ production process is indispensable for anammox engineering practices.

Recently, the high $\mathrm{NO}_{2}^{-}-\mathrm{N}$ producing from $\mathrm{NO}_{3}^{-}-\mathrm{N}$ reduction was observed in partial denitrification $\left(\mathrm{PD}, \mathrm{NO}_{3}^{-}-\mathrm{N}\right.$ $\left.\rightarrow \mathrm{NO}_{2}^{-}-\mathrm{N}\right)$ process and over $80 \%$ nitrate-to-nitrite transformation ratio (NTR) was obtained [6, 7], indicating a more stable alternative to providing substrate for anammox bacteria compared with current extensively studied partial nitritation technology [8]. Cao et al. firstly enriched $\mathrm{NO}_{2}^{-}-\mathrm{N}$ accumulation sludge using sludge fermentation liquid as external organics and a robust high nitrite of $20.91 \pm 0.52$ $\mathrm{mg} / \mathrm{L}$ was obtained in a 108-day operation [6]. Du et al. proposed a novel two-stage PD and anammox process in two isolated sequencing batch reactors (SBRs), where anammox-SBR nitrate effluent was fed into post PD-SBR to operate $\mathrm{NO}_{3}^{-}-\mathrm{N}$ reduction process with $\mathrm{NO}_{2}^{-}-\mathrm{N}$ as final product, and then $\mathrm{NO}_{2}^{-}-\mathrm{N}$ backflow to anammox-SBR for the purpose of advanced nitrogen removal [9]. Moreover, a single-reactor (i.e., upflow anaerobic sludge blanket, UASB) for simultaneous PDA was also developed, a 225-days operation demonstrated that the relatively low total nitrogen (TN) effluent concentration of $6.56 \mathrm{mg} / \mathrm{L}$ achieved even in a cold temperature $\left(17.5^{\circ} \mathrm{C}\right)$. These experimental results provided a new insight on the nitrogen removal when combined with economical and sustainable anammox process, thus gave a summary and discussion on the current status of researches and future perspectives of PDA seemed necessary [8]. Our view was shifted to this promising coupling process and considerable novel outcomes were noticed, including influencing factors, principled characteristics, and economical analyses to elucidate this significant cost-effective method. This would lessen our knowledge gap for PDA latest researches.

Increasing interest focused on combining $\mathrm{PD}$ with anammox for treating $\mathrm{NH}_{4}^{+}-\mathrm{N}$ and $\mathrm{NO}_{3}{ }^{-} \mathrm{N}$ contained wastewater, and numerous lab-scale actual wastewater treatment by PDA has been reported, i.e., domestic and nitrate contained wastewater (simulated industrial nitrate wastewater) [10-12], tertiary/secondary municipal sewage [13-16], high strength anammox-based wastewater [9, 17-20]. Nevertheless, there has been limited literature to show us comprehensive knowledge of PDA potential application, which might accelerate the popularization of PDA process. Last but not least, future trends for applications in extensive wastewater treatment and the issues that merit further study were pointed out to quickly establish a full-scale PDA process.

\section{Characteristics of PDA Coupling Process}

As we all known, the key reason for efficient nitrogen removal via PDA process was the coexistence of diverse microbial flora, owing to PD biomass known as classical heterotrophic bacteria along with intense proliferation growth might lead to autotrophic anammox bacteria possibly inhibited. Notably, maintaining dominant anammox nitrogen removal pathway was essential, since researchers have reported that anammox contributed more than 95\% nitrogen removal in PDA [11]. On the other hand, PD occurred ahead of anammox was a prerequisite due to $\mathrm{NO}_{2}{ }^{-} \mathrm{N}$-electron acceptor supply must be warranted for anammox microbes [1]. Additional, denitrifying bacteria would compete for $\mathrm{NO}_{2}^{-}-\mathrm{N}$ with anammox and destory the effluent quality once the latter activity was suppressed [21, 22]. Overall, how to balance the activity among the PD and anammox biomass was of importance to gaining satisfactory nitrogen removal. Here we showed that critical factors influenced the PDA coupling process and principled characteristics of it, moreover, economical analyses were conducted to highlight the predominat advantages.

\subsection{Key Influencing Factors}

\subsubsection{Carbon Sources}

PD organisms was considered easily exploit small molecule organics to conduct denitrification process [23, 24]. The type of carbon source can significantly influence the $\mathrm{NO}_{2}^{-}-\mathrm{N}$ accumulation performance. It could be attributed by diverse organics affected the selection and enrichment of $\mathrm{NO}_{2}{ }^{-}$-N-accumulating bacteria [24], and the discrepency of $\mathrm{NO}_{3}{ }^{-}-\mathrm{N}$ and $\mathrm{NO}_{2}^{-}-\mathrm{N}$ reduction rates would also emerge [7, 25]. Previous literatures have evidenced that simple micromolecule organic materials could easily harvest $\mathrm{NO}_{2}^{-}-\mathrm{N}$ accumulating organisms compared with complex carbon source. For instance, ethanol [26], methanol [23], acetate [27], even the biodegradable organics in urban sewage were exploited as denitrifiers electronic donors. However, easily biodegradable organics were rarely detected in current practical wastewater, i.e., municipal wastewater, sludge digestion solution and manufacturing wastewater. Therefore, external carbon sources were frequently added into PDA reactor to support $\mathrm{NO}_{2}^{-}-\mathrm{N}$ production when applied in actual wastewater. Du et al. conducted two sludge nitrification and PDA reactor to treat real municipal sewage and artificial nitrate wastewater with sodium acetate solution as external organics, achieving as low as $5 \mathrm{mg} / \mathrm{L}$ TN effluent despite frequent temperature fluctuations $\left(16.3 \sim 25.7^{\circ} \mathrm{C}\right)$ [10]. In addition, Ji et al. successfully coupled in-situ fermentation with PDA in a single reactor for advanced nitrogen removal from domestic and nitrate-containing wastewater, and the slowly biodegradable organics could be hydrolyzed and acidized to volatile fatty acids (VFAs) via fermentation, thus in-situ carbon source generated for further $\mathrm{NO}_{3}{ }^{-}-\mathrm{N}$ reduction without external addition [11]. This provided new insight into practical application of PDA in a cost-effective and environmental-friendly way.

Endogenous partial dentirificaiton (EPD) driven by denitrifying glycogen accumulating organisms (DGAOs) provided another alternative to produce $\mathrm{NO}_{2}{ }^{-} \mathrm{N}$ in mainstream anammox-based systems [28]. Previous researches 
demonstrated that DGAOs played an important role in nitrogen removal by sufficiently utilizing the organic carbon in raw wastewater to form intracellular poly-hydroxyalkanoates (PHAs) and then use them to conduct denitrification, and a high NTR of $88.7 \%$ obtained even as reactor temperature was decreased from $25^{\circ} \mathrm{C}$ to $13.5^{\circ} \mathrm{C}$ [29]. It could be concluded that EPD system has the potential to provide stable $\mathrm{NO}_{2}^{-}-\mathrm{N}$ for mainstream anammox though exposed to low temperature. A novel SNPR process was established which based on anammox, endogenous partial-denitrification and denitrifying dephosphatation to treat mainstream wastewater and excellent removal performance was achieved. Anammox pathway was proved to contribute $82.9 \%$ of the overall nitrogen removal because of the stable $\mathrm{NO}_{2}^{-}-\mathrm{N}$ production from $\mathrm{NO}_{3}^{-}-\mathrm{N}$ via EPD [30]. This indicated that the novel SNPR process has promising prospect to obtain advanced nitrogen and phosphorus removal in the mainstream of wastewater treatment plants.

\subsection{2. $\mathrm{COD} / \mathrm{NO}_{3}^{-}-\mathrm{N}$}

Limited $\mathrm{COD} / \mathrm{NO}_{3}{ }^{-}-\mathrm{N}$ means low level $\mathrm{COD}$ or sufficient $\mathrm{NO}_{3}^{-}-\mathrm{N}$ in raw wastewater, which was critical factor for terminating $\mathrm{NO}_{3}^{-}-\mathrm{N}$ reduction only to $\mathrm{NO}_{2}^{-}-\mathrm{N}$. The ratio of $\mathrm{COD} / \mathrm{NO}_{3}{ }^{-} \mathrm{N}$ largely determined the denitrification process and controlled the reduction rate of $\mathrm{NO}_{3}{ }^{-} \mathrm{N}$ [26]. Widely reported appropriate $\mathrm{COD} / \mathrm{NO}_{3}{ }^{-} \mathrm{N}$ ratio for $\mathrm{PD}$ process ranged from 2.0 3.5, of which high NTR performance and anammox bacteria suitable influent substrate $\left(\mathrm{NH}_{4}{ }^{+}-\mathrm{N} / \mathrm{NO}_{2}{ }^{-} \mathrm{N}=1.30\right)$ could be available $[8,22,31]$. However, chemoautotrophic anammox bacteria directly converted $\mathrm{NH}_{4}{ }^{+}-\mathrm{N}$ and $\mathrm{NO}_{2}{ }^{-} \mathrm{N}$ into nitrogen gas without carbon source addition and organics played a negative role in this process [32]. On the other hand, when the influent contains suitable organics, the nitrogen removal efficiency can be enhanced by denitrification. It was reported that the nitrogen removal efficiency of the anammox process was improved at a $\mathrm{COD} / \mathrm{N}$ ratio of 0.8 [33]. The effect of $\mathrm{COD} / \mathrm{N}$ ratio on completely autotrophic nitrogen removal over nitrite (CANON) process was also investigated, the high $\mathrm{COD} / \mathrm{N}$ ratio performed suppression on the bioactivity and biodiversity of both AOB (ammonia-oxidizing bacteria) and anammox bacteria, the suppressing threshold of $\mathrm{COD} / \mathrm{N}$ ratio 1.7 was favorable for nitrogen removal [34, 35]. Thus, pretreatment of high strength organics wastewater should be performed to alleviate excess COD cause completely denitrification and avoid organic toxicity for anammox bacteria.

\subsection{3. $\mathrm{pH}$}

The high $\mathrm{pH}$ was considered as an effective strategy to accumulate $\mathrm{NO}_{2}^{-}-\mathrm{N}$ in the development of denitrification process $[24,36]$. The reduction of $\mathrm{NO}_{3}^{-}-\mathrm{N}$ to $\mathrm{N}_{2}$ in denitrification is a consecutive four-step enzymatic reaction, which was related to the electronic reception, transmission and consumption [8]. High $\mathrm{pH}$ would reduce the rate of carbon oxidation in denitrification process, and further intensified the electronic competition between denitrifying enzymes [37]. Long-term or short-term effect of high $\mathrm{pH}$ on $\mathrm{NO}_{2}^{-}-\mathrm{N}$ accumulation rate (NAR) were investigated [24, 36], and as high as $57 \%$ NAR achieved during 420-day operation under $\mathrm{pH}$ of 9.0 [36]. Similarily, anammox communities had high activities in alkaline environment and $\mathrm{pH}$ of $7.5 \sim 8.5$ was prior to anammox bacterial proliferation [38]. In general, high alkalinity conditions were not usually found in actual wastewater. It is of noted that, denitrification process consumed hydrogen ions and generated hydrogen peroxide, thus $\mathrm{pH}$ of the system significantly increased. The phenomenon was termed as denitrification self-alkalization $[39,40]$. Previous study reported that the self-alkalization of denitrifying automatic circulation (DAC) reactor resulted in a large increase of $\mathrm{pH}$ up to 9.20 and caused a tremendous accumulation of $\mathrm{NO}_{2}^{-}-\mathrm{N}$ up to $451.1 \pm 49.0 \mathrm{mgN} / \mathrm{L}^{-}$at $\mathrm{NO}_{3}{ }^{-} \mathrm{N}$ loading rate (NLR) of $55 \mathrm{kgN} /\left(\mathrm{m}^{3} \cdot \mathrm{d}\right)$ [39]. For this reason, the alkaline micro-environment was easy to form whether in a two-stage or single-stage PDA system, and there was no need to increase the influent $\mathrm{pH}$ with chemicals addition. This further confirmed the feasibility of coupling $\mathrm{PD}$ with anammox to treat $\mathrm{NH}_{4}{ }^{+}-\mathrm{N}$ and $\mathrm{NO}_{3}{ }^{-}-\mathrm{N}$ containing wastewater.

\subsubsection{Sludge Morphology}

Flocs, granular aggregates and biofilms were the common life forms of microbe. Resisting adverse environments and facilitating the exchange of products and signal between bacteria were attractive features in granules and biofilms [41]. At present, granule-based PD sludge became a hot topic of researchers, high-loading or low-loading rate were used to explore the granulation of PD sludge, granulation mechanism and superior NTR performance were obtained [42-44]. Nevertheless, there has been broad gaps for us to understand the $\mathrm{NO}_{2}^{-}-\mathrm{N}$ accumulation performance via biofilm-based $\mathrm{PD}$ process. More efforts should be taken to enrich PD biofilm carriers, which would be significant to provide stable electron acceptors for anammox bacteria. The current study described the start-up of PDA process with mature PD and anammox flocculent or granule mixture sludge as inoculum $[12,13]$, also DEnitrifying AMmonium OXidation (DEAMOX) biomass $[45,46]$. Furthermore, Zhang et al. firstly established a novel biofilm DEAMOX system in a sequencing biofilm batch reactor (SBBR) for actual wastewater treatment, after 240 days of operation, TN removal efficiency maintained at 93.0\% with biofilm growth [47]. High anammox activity was obtained in biofilms implied that mature biofilms formed on carriers and the anammox bacteria were sufficient enriched in DEAMOX-SBBR system [47].

\subsection{Principled Characteristics}

Two- and single-stage reactors were the common form of PDA process. The separation technology was the two independent process in which $\mathrm{NO}_{2}{ }^{-}-\mathrm{N}$ generation and nitrogen removal with $\mathrm{PD}$ microorganisms and anammox bacteria as the absolute dominant community, effectively avoiding the microbe competition on $\mathrm{NO}_{2}^{-}-\mathrm{N}$ substrate and living space. In this fashion, the carbon source was fully utilized by denitrifiers to significantly reduce the organic matter into the 
post-anammox reactor. For example, municipal sewage and industrial nitrate wastewater firstly entered the PD reactor, and $\mathrm{NO}_{3}{ }^{-}-\mathrm{N}$ reduction easily occurred by utilizing biotic carbon source in raw wastewater. However, because of the low molecule carbon source content, it was necessary to invest external electron donor to achieve appropriate anammox reaction of $\mathrm{NO}_{2}{ }^{-}-\mathrm{N} / \mathrm{NH}_{4}{ }^{+}-\mathrm{N}=1.32$. Subsequently, the effluent was recycled to $\mathrm{PD}$ reactor for deep-level nutrient removal [9, 27]. Cao et al. established an innovative two-stage PDA process was applied to remove the nitrate nitrogen (20-40 mg $\mathrm{N} / \mathrm{L}$ ) from municipal secondary effluent, with raw wastewater providing organic matters for denitrifiers, the final effluent TN and COD concentration were as low as $4.0 \mathrm{mg} \mathrm{N} / \mathrm{L}$ and 30.1 $\mathrm{mg} / \mathrm{L}$ [13]. Du et al. optimized the feeding ratio between the two type wastewaters and external carbon dosage to obtain satisfactory effluent nitrogen concentration even though high-strength nitrate wastewater introduced (1000 mg N/L), the excellent removal efficiency of $\mathrm{NO}_{3}{ }^{-} \mathrm{N}$ and $\mathrm{NH}_{4}{ }^{+}-\mathrm{N}$ achieved $95.8 \%$ and $92.8 \%$, respectively [27].

Based on the recently results, there was a positive correlation between anammox and denitrification bacteria activity, and the synergism of which microbes greatly improved the system $\mathrm{TN}$ removal performance [32, 48, 49]. Li et al. found that the transformation of anoxic area of municipal sewage plant into MBBR enhanced the loss of nitrogen in the system, and took samples for metagenome sequencing and mass balance analysis [14]. It was proved that the up-regulation of nitrate reductase gene in anoxic carrier biofilm improved the NTR performance, promoted the growth of anammox in the mainstream process, which greatly enhanced the denitrification in the continuous flow of domestic sewage treatment [14]. A single-stage reactor was based on the in-situ reduction of $\mathrm{NO}_{3}{ }^{-} \mathrm{N}$ by denitrifying bacteria and supplied $\mathrm{NO}_{2}^{-}-\mathrm{N}$ to anammox to directly remove $\mathrm{NH}_{4}^{+}-\mathrm{N}$ and $\mathrm{NO}_{2}^{-}-\mathrm{N}$ simultaneously. Anammox biomass can utilize a small amount of carbon source and $\mathrm{NO}_{3}^{-}-\mathrm{N}$ under anaerobic condition, which made it show resistant to high $\mathrm{C} / \mathrm{N}$ ratio wastewater.

\subsection{Economical Analyses}

PD-based anammox technology held great economical advantages in terms of oxygen consumption, carbon demand, biomass production as well as $\mathrm{CO}_{2}$ production. No oxygen was consumed (100\% savings), $1.14 \mathrm{~g}$ COD was required (80.0\% savings), and $0.44 \mathrm{~g}$ MLVSS was produced $(64.8 \%$ fewer) in the PD-Anammox process compared with conventional nitrification/denitrification process, demonstrating the PD-Anammox process was economically favorable [13]. Cao et al. compared the PDA and PNA aeration depletion in a $100000 \mathrm{~m}^{3} / \mathrm{d}$ full-scale wastewater treatment plant, the calculated results showed that $23760 \mathrm{~kg}$ oxygen would be consumed in the integrated PDA process, which was $4.3 \%$ lower than that of the PNA process $(24780 \mathrm{~kg})$ [50]. The reason for this was that a portion of the influent organic matter was diverted to the PDA reactor for denitrification rather than being oxidized in the pretreatment stage, which reduced the overall oxygen consumption. Therefore, the integrated PDA process was comparable with the PNA process in terms of aeration requirements and organic matter recovery as biogas.

As for retrofitting currently conventional denitrifying biofilter (DNBF) to a novel economically attractive denitratation/anammox biofilter (DABF) for nitrate removal from secondary effluent $[15,51,52]$, Ma et al. found that organic carbon source consumption and backwash sludge production in the DABF were significantly reduced by $63 \%$ and $70 \%$ compared with DNBF, respectively [51]. Outstanding economical advantages such as saving $7.9 \%$ of aeration consumption, $56.8 \%$ of carbon source cost, $20.2 \%$ of sludge production, and $28.1 \%$ of $\mathrm{CO}_{2}$ emission were elucidated in a $\mathrm{A} / \mathrm{A} / \mathrm{O}$ wastewater treatment plant with post-DABF process [15]. PDA biofilter was confirmed to be a feasible process to advanced wastewater treatment, which could save aeration consumption and carbon source addition, and reduce sludge production.

\section{Recent Advances in PDA Coupling Process}

\subsection{Advanced Nitrogen Removal from Tertiary Municipal Sewage}

High nitrate concentration in the final effluent of wastewater treatment plants (WWTPs), could not meet the increasing stringent discharge limits and challenged energy-autarky or even energy-positive WWTPs in future. Denitrification was usually developed in the $\mathrm{NO}_{3}^{-}-\mathrm{N}$ reduction process of secondary effluent. But too much organic materials addition and excess waste sludge seriously deviated from the sustainable development goal of economic and environmental. Previous study has showed that two-stage PDA process could support the secondary effluent treatment, the $\mathrm{NO}_{3}{ }^{-} \mathrm{N}$ wastewater was firstly fed to $\mathrm{PD}$ reactor to produce $\mathrm{NO}_{2}^{-}-\mathrm{N}$ along with the low carbon/nitrogen ratio $(\mathrm{C} / \mathrm{N})$ municipal sewage, then the effluent from $\mathrm{PD}$ was pumped to the anammox reactor for further nitrogen removal, the excellent removal efficiency of $\mathrm{NH}_{4}{ }^{+}-\mathrm{N}, \mathrm{NO}_{3}{ }^{-}-\mathrm{N}$ and $\mathrm{COD}$ were $95.2 \%$, $97.9 \%$ and $81.6 \%$, respectively [13]. Additionally, DNBF was thought to be a feasible strategy for further $\mathrm{NO}_{3}{ }^{-} \mathrm{N}$ reduction, whereas abundant carbon source addition and frequent backwash operation was involved due to relatively high sludge yield $[15,51,52]$. For this reason, DABF was constructed for removing $\mathrm{NO}_{3}{ }^{-}-\mathrm{N}$ from secondary effluent with carbon source in raw wastewater as electronic donor, nitrogen banlance analysis revealed that $93 \%$ of $\mathrm{N}_{2}$ produced in DABF was via anammox, DABF biofilm reduced $\mathrm{NO}_{2}^{-}-\mathrm{N}$ using $\mathrm{NH}_{4}^{+}-\mathrm{N}$ as the electron donor, and accumulated $\mathrm{NO}_{2}^{-}-\mathrm{N}$ during denitratation, thus providing $\mathrm{NO}_{2}^{-}-\mathrm{N}$ for the anammox bacteria [51]. More than $80 \% \mathrm{TN}$ removal was available with the average effluent $\mathrm{TN}$ concentration was $7.82 \mathrm{mg} / \mathrm{L}$, indicated the promising PDA biofilter technology once in practical application. 


\subsection{Post-anammox Treatment of Nitrogen-Rich Wastewater}

The developed industrial activities produced a large amount of industrial ammonia-rich wastewater, i.e., glutamate wastewater, pharmaceutical wastewater, piggery wastewater, landfill leachate, etc. Nowadays, PN-based anammox technology provided a sustainable and environmental way for such wastewater treatment without carbon source addition. However, it is difficult to achieve high standard effluent via PNA process because excessive $\mathrm{NO}_{3}{ }^{-} \mathrm{N}$ produced as an inherent issue. For this reason, an economical process for enhancing nitrogen removal from post-anammox $\mathrm{NO}_{3}{ }^{-} \mathrm{N}$-rich technology which combined PD and anammox could be established for advanced nitrogen removal. Wang et al. introduced mature leachate PNA effluent to one-stage PDA-SBR, under the concentration of influent $\mathrm{NH}_{4}{ }^{+}-\mathrm{N}$ and $\mathrm{NO}_{3}{ }^{-} \mathrm{N}$ of $47.5 \mathrm{mg} / \mathrm{L}$ and $93.7 \mathrm{mg} / \mathrm{L}$ on average, $\mathrm{TN}$ removal efficiency of $84.8 \%$ was obtained with the effluent TN less than $20 \mathrm{mg} / \mathrm{L}$ [18]. The ORP and $\mathrm{pH}$ could potentially be used as control parameters to maintain the stability of combined process [18]. Similarly, by applying the strategy of PNA coupled with PDA, $\mathrm{NH}_{4}{ }^{+}-\mathrm{N}$ and TN removal efficiencies of over $95 \%$ were achieved during leachate treatment. In addition, providing an electron donor for $\mathrm{PD}$ of $\mathrm{NO}_{3}{ }^{-} \mathrm{-N}$ using diluted leachate is feasible for producing $\mathrm{NO}_{2}^{-}-\mathrm{N}$ for subsequent anammox [20]. Overall, PD in cooperation with anammox is a reliable and economic strategy for post-anammox $\mathrm{NO}_{3}{ }^{-} \mathrm{N}$-rich treatment with lower carbon requirements, and can help meet the stringent environmental guidelines for $\mathrm{TN}$ removal.

\subsection{Simultaneous Nitrogen Removal from Domestic and Nitrate-Contained Wastewater}

It is well noted that, industrial nitrate wastewater is mainly distributed in the industrial park, so the establishment of MWTPs with PDA as the core treatment process in the park has bright application prospects, which could achieve simultaneous nitrogen removal from domestic sewage and industrial nitrate wastewater. The lab-scale PDA has been verified for high nitrate and municipal wastewater treatment process, in which $\mathrm{NO}_{3}{ }^{-} \mathrm{N}(1000 \mathrm{mg} / \mathrm{L})$ wastewater and municipal sewage (COD $182.5 \mathrm{mg} / \mathrm{L}, \mathrm{NH}_{4}^{+}-\mathrm{N} 58.3 \mathrm{mg} / \mathrm{L}$ ) were simultaneously introduced to the $\mathrm{PD}$ reactor for $\mathrm{NO}_{2}^{-}-\mathrm{N}$ accumulation, and the $\mathrm{NH}_{4}{ }^{+}-\mathrm{N}, \mathrm{NO}_{2}{ }^{-}-\mathrm{N}$ in effluent of $\mathrm{PD}$ were removed in subsequent anammox reactor. A satisfactory nitrogen removal was achieved by optimizing the volume ratios of influent $\mathrm{NO}_{3}^{-}-\mathrm{N}$ and municipal sewage, as well as the external organic matter dosage, indicated that PDA offered an economically and technically attractive approach in the high $\mathrm{NO}_{3}{ }^{-} \mathrm{N}$ wastewater treatment. Recently studies introduced low-strength nitrate wastewater and domestic wastewater into one-stage PDA reactor, excellent effluent quality was obtained with $<5 \mathrm{mg} / \mathrm{L}$ of total nitrogen (TN) despite frequent temperature fluctuations $\left(25.7-16.3^{\circ} \mathrm{C}\right)$ [10]. Metagenomic revealed that the abundances of cytoplasmic nitrate reductase (58706 hits) and periplasmic nitrate reductase (70540 hits) were much higher than copper nitrite reductase (16436 hits) and cytochrome cd 1 nitrite reductase (14264 hits), potentially contributing to the occurrence of PD [11].

\section{Future Trends of the PDA Coupling Process}

PD-based anammox wastewater system has been successfully applied into actual domestic sewage [10, 11], landfill leachate [53], and simulated industrial nitrate-contained wastewater, yet many hazardous materials in nitrate-contained wastewater were all neglected. The heavy metals, such as chromium, nickel, copper, zinc, etc., had strong cytotoxic and cell lysis effects, also fluoride, which had evident inhibition of enzyme activity [50]. None researches depicted the potential toxic effects of such substances in raw nitrate wastewater on $\mathrm{PD}$, which was warranted to be investigated in future work.

From the micromolecule perspective, there are still knowledge gaps on the inter and intra-relationships between the various groups of bacteria in the mixed PDA culture [8]. The new molecular tools, such as metagenomic and metatranscriptomic have provided new insights into the complex nitrogen metabolic pathways of the involved bacteria [54]. Wang et al. applied metagenomic and metatranscriptomic approaches to gain comprehensive and deep understanding of the nitrogen metabolic pathways in a lab-scale single PDA bioreactor, $\mathrm{NO}_{3}^{-}-\mathrm{N}$ reduction process was found to be mainly ralated to the activation of the $n a p \mathrm{~A} / \mathrm{B} / \mathrm{C}$ genes instead of $\operatorname{nar} \mathrm{G} / \mathrm{H}$ genes, the nitrogen metabolic network was also established to improve our knowledge of the nitrogen metabolic mechanisms [54]. Notably, the specific roles of each species of denitrifying and anammox bacteria should be elucidated to shed a new light for engineering application of PDA technology.

Many studies have identified that PDA could achieve advanced nitrogen removal, where anammox by-products $\mathrm{NO}_{3}{ }^{-} \mathrm{N}$ could be reused by denitrification process to producing $\mathrm{NO}_{2}^{-}-\mathrm{N}$, this is also the unique advantages of PDA process compared with other biological nitrogen removal technology $[11,55]$. However, phosphate as normal nutrient in real wastewater seemed unacceptable for PDA process, and novel technology for synchronous advanced nitrogen and phosphorus removal should be established. Considering this, we proposed an innovative simultaneous partial denitrification, anammox and denitrifying phosphorus removal (SPADPR) in a continuous flow reactor, since DPR was a promising opportunity for phosphorus removal with minimal waste sludge and minor carbon demand. The schematic diagram of SPADPR-ABR reactor exploited was shown in Figure 1. In this process, three anaerobic baffled reactor (ABR) chambers were operated as DPR area (termed as DPR-ABR), where the first chamber used as anaerobic P-release zone and other two compartments functioned as anoixc P-absorption with $\mathrm{NO}_{3}{ }^{-}-\mathrm{N} / \mathrm{NO}_{2}{ }^{-}-\mathrm{N}$ as electron acceptors. Continuous stirred tank reactor (CSTR) reactor was used to conduct PDA process, 
termed as PDA-CSTR. In detail, $\mathrm{NH}_{4}{ }^{+}-\mathrm{N}, \mathrm{PO}_{4}{ }^{3-}-\mathrm{P}$ and COD contained wastewater (i.e., domestic sewage) was directly introduced into A1-DPR chamber to achieve phosphorus releasing under anaerobic condition, artificial nitrate wastewater was pumped into A2 chamber and implemented P-removal in the subsequent compartment (A2-3). Finally, the residual $\mathrm{NO}_{3}{ }^{-}-\mathrm{N}, \mathrm{NH}_{4}{ }^{+}-\mathrm{N}$, and little $\mathrm{COD}$ entered PDA reactor to carry out advanced nitrogen removal via coordination of PD and anammox process. Overall, significantly synchronous nitrogen and phosphorus removal achieved without any aeration demand and external carbon source, thus a novel cost-effective and highly-efficient nutrient removal method was successfully established.

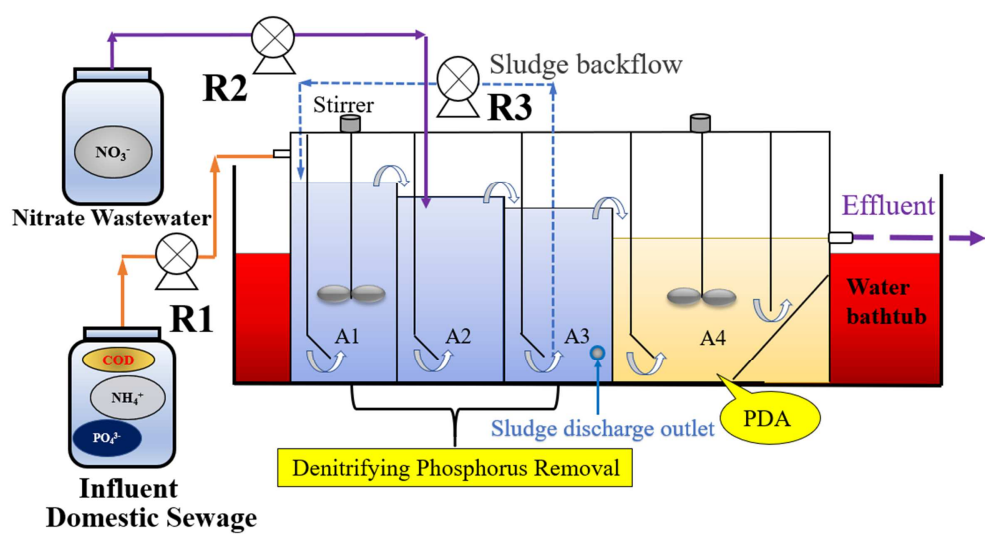

Figure 1. Schematic diagram of SPADPR-ABR reactor.

\section{Conclusion}

The PD-based anammox process offers a promising solution to $\mathrm{NH}_{4}^{+}-\mathrm{N}$ and $\mathrm{NO}_{3}{ }^{-}-\mathrm{N}$ containing wastewater in a cost-effective and environmental-sustainable way. The highly-efficient nitrogen removal could be achieved and maintain a relatively stable despite exposed to long-term low temperature condition. The coupling system holds significant advantages in dealing with low/high strength wastewater by two- or single-stage integrations, such as $50 \%$ reduction in aeration energy consumption, $80 \%$ decrease in carbon source demand, and lower greenhouse $\left(\mathrm{N}_{2} \mathrm{O}\right)$ as well as biomass production. Numerous lab-scale PDA process for actual wastewater treatment has been well developed for advanced nitrogen removal but practical engineering application still be lacking. More efforts are recommended on the controllable strategies for engineering practices and the penetrating understanding of microbial mechanism and metabolic pathway for the multispecies nitrogen transformation process.

\section{Acknowledgements}

This work was financially supported by Natural Science Foundation of China (51578353 and 51808367); Funding Project of Jiangsu Natural Science Research (BK20160356); Research Fundation of Suzhou University of Science and Technology (XKZ2018002).

\section{References}

[1] B. Ma, X. Xu, Y. Wei, C. Ge, Y. Peng, Recent advances in controlling denitritation for achieving denitratation/anammox in mainstream wastewater treatment plants, Bioresour Technol $299(2020) 122697$.
[2] B. Ma, S. Wang, S. Cao, Y. Miao, F. Jia, R. Du, Y. Peng, Biological nitrogen removal from sewage via anammox: Recent advances, Bioresour Technol 200 (2016) 981-990.

[3] M. Ali, S. Okabe, Anammox-based technologies for nitrogen removal: Advances in process start-up and remaining issues, Chemosphere 141 (2015) 144-153.

[4] M. Nsenga Kumwimba, T. Lotti, E. Senel, X. Li, F. Suanon, Anammox-based processes: How far have we come and what work remains? A review by bibliometric analysis, Chemosphere 238 (2020) 124627.

[5] J. Li, J. Li, R. Gao, M. Wang, L. Yang, X. Wang, L. Zhang, Y. Peng, A critical review of one-stage anammox processes for treating industrial wastewater: Optimization strategies based on key functional microorganisms, Bioresour Technol 265 (2018) 498-505.

[6] S. Cao, S. Wang, Y. Peng, C. Wu, R. Du, L. Gong, B. Ma, Achieving partial denitrification with sludge fermentation liquid as carbon source: the effect of seeding sludge, Bioresour Technol 149 (2013) 570-574.

[7] S. Ge, Y. Peng, S. Wang, C. Lu, X. Cao, Y. Zhu, Nitrite accumulation under constant temperature in anoxic denitrification process: The effects of carbon sources and COD/NO(3)-N, Bioresour Technol 114 (2012) 137-143.

[8] R. Du, Y. Peng, J. Ji, L. Shi, R. Gao, X. Li, Partial denitrification providing nitrite: Opportunities of extending application for anammox, Environ Int 131 (2019) 105001.

[9] R. Du, Y. Peng, S. Cao, S. Wang, C. Wu, Advanced nitrogen removal from wastewater by combining anammox with partial denitrification, Bioresour Technol 179 (2015) 497-504.

[10] R. Du, S. Cao, H. Zhang, X. Li, Y. Peng, Flexible Nitrite Supply Alternative for Mainstream Anammox: Advances in Enhancing Process Stability, Environ Sci Technol 54 (10) (2020) 6353-6364. 
[11] J. Ji, Y. Peng, B. Wang, X. Li, Q. Zhang, Synergistic Partial-Denitrification, Anammox, and in-situ Fermentation (SPDAF) Process for Advanced Nitrogen Removal from Domestic and Nitrate-Containing Wastewater, Environ Sci Technol 54 (6) (2020) 3702-3713.

[12] R. Du, S. Cao, B. Li, S. Wang, Y. Peng, Simultaneous domestic wastewater and nitrate sewage treatment by DEnitrifying AMmonium OXidation (DEAMOX) in sequencing batch reactor, Chemosphere 174 (2017) 399-407.

[13] S. Cao, R. Du, Y. Peng, B. Li, S. Wang, Novel two stage partial denitrification (PD)-Anammox process for tertiary nitrogen removal from low carbon/nitrogen $(\mathrm{C} / \mathrm{N})$ municipal sewage, Chemical Engineering Journal 362 (2019) 107-115.

[14] J. Li, Y. Peng, L. Zhang, J. Liu, X. Wang, R. Gao, L. Pang, Y. Zhou, Quantify the contribution of anammox for enhanced nitrogen removal through metagenomic analysis and mass balance in an anoxic moving bed biofilm reactor, Water Res 160 (2019) 178-187.

[15] B. Cui, Q. Yang, X. Liu, W. Wu, Z. Liu, P. Gu, Achieving partial denitrification-anammox in biofilter for advanced wastewater treatment, Environ Int 138 (2020) 105612.

[16] X. Zhan, Y. Yang, F. Chen, S. Wu, R. Zhu, Treatment of secondary effluent by a novel tidal-integrated vertical flow constructed wetland using raw sewage as a carbon source: Contribution of partial denitrification-anammox, Chemical Engineering Journal 395 (2020).

[17] S. Cao, R. Du, M. Niu, B. Li, N. Ren, Y. Peng, Integrated anaerobic ammonium oxidization with partial denitrification process for advanced nitrogen removal from high-strength wastewater, Bioresour Technol 221 (2016) 37-46.

[18] Z. Wang, L. Zhang, F. Zhang, H. Jiang, S. Ren, W. Wang, Y. Peng, Enhanced nitrogen removal from nitrate-rich mature leachate via partial denitrification (PD)-anammox under real-time control, Bioresour Technol 289 (2019) 121615.

[19] L. Wu, Z. Li, S. Huang, M. Shen, Z. Yan, J. Li, Y. Peng, Low energy treatment of landfill leachate using simultaneous partial nitrification and partial denitrification with anaerobic ammonia oxidation, Environ Int 127 (2019) 452-461.

[20] L. Wu, Z. Li, C. Zhao, D. Liang, Y. Peng, A novel partial-denitrification strategy for post-anammox to effectively remove nitrogen from landfill leachate, Sci Total Environ 633 (2018) 745-751.

[21] B. Ma, W. Qian, C. Yuan, Z. Yuan, Y. Peng, Achieving Mainstream Nitrogen Removal through Coupling Anammox with Denitratation, Environ Sci Technol 51 (15) (2017) 8405-8413.

[22] M. Zhang, S. Wang, B. Ji, Y. Liu, Towards mainstream deammonification of municipal wastewater: Partial nitrification-anammox versus partial denitrification-anammox, Sci Total Environ 692 (2019) 393-401.

[23] Y. Fernandez-Nava, E. Maranon, J. Soons, L. Castrillon, Denitrification of high nitrate concentration wastewater using alternative carbon sources, J Hazard Mater 173 (1-3) (2010) 682-8.

[24] L. Shi, R. Du, Y. Peng, Achieving partial denitrification using carbon sources in domestic wastewater with waste-activated sludge as inoculum, Bioresour Technol 283 (2019) 18-27.
[25] R. Du, Y. Peng, S. Cao, B. Li, S. Wang, M. Niu, Mechanisms and microbial structure of partial denitrification with high nitrite accumulation, Appl Microbiol Biotechnol 100 (4) (2016) 2011-2021.

[26] T. Le, B. Peng, C. Su, A. Massoudieh, A. Torrents, A. Al-Omari, S. Murthy, B. Wett, K. Chandran, C. DeBarbadillo, C. Bott, H. De Clippeleir, Impact of carbon source and $\mathrm{COD} / \mathrm{N}$ on the concurrent operation of partial denitrification and anammox, Water Environ Res 91 (3) (2019) 185-197.

[27] R. Du, S. Cao, Y. Peng, H. Zhang, S. Wang, Combined Partial Denitrification (PD)-Anammox: A method for high nitrate wastewater treatment, Environ Int 126 (2019) 707-716.

[28] X. Wang, J. Zhao, D. Yu, G. Chen, S. Du, J. Zhen, M. Yuan, Stable nitrite accumulation and phosphorous removal from nitrate and municipal wastewaters in a combined process of endogenous partial denitrification and denitrifying phosphorus removal (EPDPR), Chemical Engineering Journal 355 (2019) $560-571$.

[29] J. Ji, Y. Peng, X. Li, Q. Zhang, Stable long-term operation and high nitrite accumulation of an endogenous partial-denitrification (EPD) granular sludge system under mainstream conditions at low temperature, Bioresour Technol 289 (2019) 121634.

[30] J. Ji, Y. Peng, B. Wang, X. Li, Q. Zhang, A novel SNPR process for advanced nitrogen and phosphorus removal from mainstream wastewater based on anammox, endogenous partial-denitrification and denitrifying dephosphatation, Water Res 170 (2019) 115363.

[31] C. Bi, D. Yu, X. Wang, S. Du, J. Wang, X. Gong, Y. Du, J. Zhao, Performance and microbial structure of partial denitrification in response to salt stress: Achieving stable nitrite accumulation with municipal wastewater, Bioresour Technol 311 (2020) 123559 .

[32] J. Li, J. Li, Y. Peng, S. Wang, L. Zhang, S. Yang, S. Li, Insight into the impacts of organics on anammox and their potential linking to system performance of sewage partial nitrification-anammox (PN/A): A critical review, Bioresour Technol 300 (2020) 122655.

[33] C. Chen, F. Sun, H. Zhang, J. Wang, Y. Shen, X. Liang, Evaluation of COD effect on anammox process and microbial communities in the anaerobic baffled reactor (ABR), Bioresour Technol 216 (2016) 571-578.

[34] X. Zhang, H. Zhang, C. Ye, M. Wei, J. Du, Effect of COD/N ratio on nitrogen removal and microbial communities of CANON process in membrane bioreactors, Bioresour Technol 189 (2015) 302-308.

[35] X. Zhang, C. Wang, P. Wu, W. Yin, L. Xu, New insights on biological nutrient removal by coupling biofilm-based CANON and denitrifying phosphorus removal (CANDPR) process: Long-term stability assessment and microbial community evolution, Sci Total Environ 730 (2020) 138952.

[36] W. Qian, B. Ma, X. Li, Q. Zhang, Y. Peng, Long-term effect of $\mathrm{pH}$ on denitrification: High $\mathrm{pH}$ benefits achieving partial-denitrification, Bioresour Technol 278 (2019) 444-449.

[37] Y. Pan, L. Ye, B. J. Ni, Z. Yuan, Effect of $\mathrm{pH}$ on $\mathrm{N}(2) \mathrm{O}$ reduction and accumulation during denitrification by methanol utilizing denitrifiers, Water Res 46 (15) (2012) 4832-4840. 
[38] Q.-G. You, J.-H. Wang, G.-X. Qi, Y.-M. Zhou, Z.-W. Guo, Y. Shen, X. Gao, Anammox and partial denitrification coupling: a review, RSC Advances 10 (21) (2020) 12554-12572.

[39] W. Li, X. Y. Shan, Z. Y. Wang, X. Y. Lin, C. X. Li, C. Y. Cai, G. Abbas, M. Zhang, L. D. Shen, Z. Q. Hu, H. P. Zhao, P. Zheng, Effect of self-alkalization on nitrite accumulation in a high-rate denitrification system: Performance, microflora and enzymatic activities, Water Res 88 (2016) 758-765.

[40] W. Li, X. Y. Lin, J. J. Chen, C. Y. Cai, G. Abbas, Z. Q. Hu, H. P. Zhao, P. Zheng, Enrichment of denitratating bacteria from a methylotrophic denitrifying culture, Appl Microbiol Biotechnol 100 (23) (2016) 10203-10213.

[41] L. Liu, M. Ji, F. Wang, S. Wang, G. Qin, Insight into the influence of microbial aggregate types on nitrogen removal performance and microbial community in the anammox process - A review and meta-analysis, Sci Total Environ 714 (2020) 136571.

[42] R. Du, S. Cao, H. Zhang, Y. Peng, Formation of partial-denitrification (PD) granular sludge from low-strength nitrate wastewater: The influence of loading rates, J Hazard Mater 384 (2020) 121273.

[43] S. Cao, Y. Peng, R. Du, H. Zhang, Characterization of partial-denitrification (PD) granular sludge producing nitrite: Effect of loading rates and particle size, Sci Total Environ 671 (2019) 510-518.

[44] S. Cao, R. Du, H. Zhang, Y. Peng, Understanding the granulation of partial denitrification sludge for nitrite production, Chemosphere 236 (2019) 124389.

[45] R. Du, S. Cao, B. Li, H. Zhang, X. Li, Q. Zhang, Y. Peng, Step-feeding organic carbon enhances high-strength nitrate and ammonia removal via DEAMOX process, Chemical Engineering Journal 360 (2019) 501-510.

[46] R. Du, S. Cao, B. Li, M. Niu, S. Wang, Y. Peng, Performance and microbial community analysis of a novel DEAMOX based on partial-denitrification and anammox treating ammonia and nitrate wastewaters, Water Res 108 (2017) 46-56.

[47] H. Zhang, R. Du, S. Cao, S. Wang, Y. Peng, Mechanisms and characteristics of biofilm formation via novel DEAMOX system based on sequencing biofilm batch reactor, J Biosci Bioeng 127 (2) (2019) 206-212.

[48] W. Chen, S. Chen, J. Wu, Biomass segregation in the granules and flocs affects the role of heterotrophic bacteria in the ANAMMOX process, Chemical Engineering Journal (2019).

[49] S. Kalyuzhnyi, M. Gladchenko, A. Mulder, B. Versprille, DEAMOX--new biological nitrogen removal process based on anaerobic ammonia oxidation coupled to sulphide-driven conversion of nitrate into nitrite, Water Res 40 (19) (2006) 3637-3645.

[50] S. Cao, A. Oehmen, Y. Zhou, Denitrifiers in Mainstream Anammox Processes: Competitors or Supporters? Environ Sci Technol 53 (19) (2019) 11063-11065.

[51] B. Ma, X. Xu, S. Ge, B. Li, Y. Wei, H. Zhu, X. Nan, Y. Peng, Reducing carbon source consumption through a novel denitratation/anammox biofilter to remove nitrate from synthetic secondary effluent, Bioresour Technol 309 (2020) 123377.

[52] B. Cui, X. Liu, Q. Yang, J. Li, X. Zhou, Y. Peng, Achieving partial denitrification through control of biofilm structure during biofilm growth in denitrifying biofilter, Bioresour Technol 238 (2017) 223-231.

[53] R. Sharp, W. Khunjar, D. Daly, J. Perez-Terrero, K. Chandran, A. Niemiec, G. Pace, Nitrogen removal from water resource recovery facilities using partial nitrification, denitratation-anaerobic ammonia oxidation (PANDA), Science of The Total Environment 724 (2020).

[54] D. Wang, Q. Zheng, K. Huang, D. Springael, X.-X. Zhang, Metagenomic and metatranscriptomic insights into the complex nitrogen metabolic pathways in a single-stage bioreactor coupling partial denitrification with anammox, Chemical Engineering Journal 398 (2020).

[55] R. Du, S. Cao, X. Li, J. Wang, Y. Peng, Efficient partial-denitrification/anammox (PD/A) process through gas-mixing strategy: System evaluation and microbial analysis, Bioresour Technol 300 (2020) 122675. 